\title{
The Urgency of Regulations Revision Related to Filing Bankruptcy and Postponing Debt Payment Obligations Amid the COVID-19 Pandemic
}

\author{
Centia Sabrina Nuriskia \\ Faculty of Law, Universitas Pembangunan Nasional Veteran Jakarta, Jakarta, Indonesia \\ Email: centiasabrinan@upnvj.ac.id \\ ORCID Link: https://orcid.org/0000-0002-1140-9990
}

Ahmad Yoga Novaliansyah

Faculty of Law, Universitas Pembangunan Nasional Veteran Jakarta, Jakarta, Indonesia

\section{Citation:}

Nuriskia, C. S. \& Novaliansyah, A. Y. (2021). The Urgency of Regulation Revision Related to Filling Bankruptcy and Postponing Debt Payemnt Obligations Amid the COVID-19 Pandemic. Lex Scientia Law Review, 5(2), 105-122, doi: https://doi.org/10.15294/lesrev.v5i 2.50383

History of Article

Received: September 29, 2021

Revised: November 09, 2021

Accepted: November 19, 2021

(C) The Author(s)

\section{(cc) (1) 80}

This work is licensed under a Creative Commons Attribution-NonCommercialShareAlike 4.0 International License. All writings published in this journal are personal views of the authors and do not represent the views of this journal and the author's affiliated institutions.

Lex Scientia Law Review published by Faculty of Law, Universitas Negeri Semarang, Indonesia in collaboration of UKM Lex Scientia. Published biannually

\begin{abstract}
The purpose of this research is to analyze the requirements of bankruptcy regulations and postponement of debt payment obligations on the increase in bankruptcy filings and delays in debt payment obligations in the middle of the COVID-19 Pandemic. This research uses a normative juridical research method with a statutory approach and a conceptual approach that is supported by primary and secondary legal materials. The results of this research indicate that the increase in filing for bankrBankruptcydelays in paying debt obligations at the Commercial Court is due to unclear rules regarding filing for bankrBankruptcyecially the requirements in filing for bank bankruptcy do not specify the amount of debt that can be filed for bankrBankruptcyre is a need for consideration in making and stipulating bankruptcy arrangements, both in the Draft Civil Procedure Code and the Bankruptcy Law and Suspension of Debt Payment Obligations, especially on issues: the amount of debtor debt, simple evidence, creditors holding guarantees in bankrBankruptcyminal confiscation in bankrBankruptcyker wage rating, bankruptcy estate settlement, and position of the arbitration award in bankruptcy cases.
\end{abstract}

\section{KEYWORDS}

Bankruptcy; Commercial Court; Covid-19; PKPU. 


\section{INTRODUCTION}

The development of national Law is a form of realizing a legal system that leads to the national interest. In terms of the national interest, namely the growth and development of laws that should empower the wider community. To support the development of the national Law, it is necessary to have deliberation and various inputs in the formation of new laws and to review whether existing legal products are still relevant for use today. Especially legal products that are used to support national economic development. The legal product must be based on the values that exist in society as well as the values that grow and develop in accordance with the culture of the Indonesian people. ${ }^{1}$

The emergence of the coronavirus disease or COVID-19, which is an infectious virus affects various sectors of life, not only in Indonesia but to all countries in the world. With the stipulation of this virus as a pandemic, the Government is increasingly preparing various policies to deal with this Covid-19 Pandemic. One of the policies made by the Government is LargeScale Social Restrictions based on Government Regulation Number 21 of 2020 concerning Large-Scale Social Restrictions in the Context of Accelerating the Handling of Corona Virus Disease 2019 (COVID-19). ${ }^{2}$ After that, there was an Instruction from the Minister of Home Affairs Number 15 of 2021 concerning the Enforcement of Restrictions on Emergency Community Activities for Corona Virus Disease 2019 in the Java and Bali Regions, which continued to change due to the nature of instructions and in each Instruction the Minister of Home Affairs regulates the extension of this PPKM.

With these policies, activities in various sectors were forced to stop. Starting from the field of Education, such as schools and campuses, places of worship, restaurants, shopping centers, tourism places, and many more that have been forced to stop temporarily, and even some are no longer operating permanently. ${ }^{3}$ The economic and business sectors are among the sectors most affected. Indonesia has experienced a slowdown in economic growth due to the COVID-19 Pandemic as a result of all the policies to control and overcome COVID-19.

According to the Central Statistics Agency (BPS), Indonesia's economic growth slowed by $2.97 \%$ (year on year), which occurred in the first quarter of 2021. When compared to the fourth quarter of 2020, Indonesia's economic

\footnotetext{
${ }^{1}$ Oksep Adhayanto, "Perkembangan Sistem Hukum Nasional", Jurnal Ilmu Hukum, Volume 4, Number 2, 2014, p. 210-211.

${ }^{2}$ Fakhrul Rozi Yamali \& Ririn Noviyanti Putri, "Dampak Covid-19 Terhadap Ekonomi Indonesia", Journal of Economics and Business, Volume 4 Number 2, 2020, p. 386.

${ }^{3}$ Abdurrahman Misno BP, Junediyono, dkk, "Covid-19: Wabah, Fitnah dan Hikmah", Pustaka Amma Alamia, Bogor, 2020, p. 386.
} 
growth decreased by $2.41 \%$. People's purchasing power currently affects economic growth. People's purchasing power is a component that is used as a measure of spending on economic growth. ${ }^{4}$ Many companies are experiencing economic bottlenecks due to COVID-19. Barriers experienced by the company start from the production process, marketing to sales which ultimately make a company unable to carry out its obligations to finance the company's operations and other costs.

To overcome the impact of the COVID-19 Pandemic, the Government has launched nine economic policies, namely:

1. There is a policy of cutting the state budget and budget

2. There is a policy to reallocate the budget

3. The existence of a guarantee policy for the procurement of goods and services

4. The existence of a cash-intensive program

5. There is a policy of providing additional cash of Rp. 50,000 to basic food cardholders

6. The existence of a policy to accelerate the implementation of preemployment cards

7. PPH Payments by the Government

8. Providing stimulus to people who do mortgages

9. The existence of a credit relaxation policy provided by the Financial Services Authority to MSEs.

In terms of this slack credit policy, the leasing or bank provides several ways, starting from extending the payment period, reducing interest rates, reducing principal arrears, reducing interest arrears, adding credit facilities to converting credit into temporary equity participation. ${ }^{5}$ Although there have been several policies to overcome the impact of the COVID-19 Pandemic by the Government, there are some business actors who are unable to cover the losses they have experienced. That way, they are forced to borrow debts from creditors for the sustainability of the company. According to the Big Indonesian Dictionary (KBBI), debt is money borrowed from other people and the obligation to pay back what has been received. ${ }^{6}$ Whereas specifically

${ }^{4}$ Dian Lestari Ningsih, "Kondisi Pertumbuhan Ekonomi saat Pandemi Covid-19 di Indonesia", Yahoo berita, June 16, 2021, accessed from https://id.berita.yahoo.com/kondisi-pertumbuhan-ekonomi-saatpandemi-080201706.html.

${ }^{5}$ Anggi Reftiana, Tuhindika Septianing, Vanny Billa Ardinna, \& Vika Lisdiyanti, "Analisis Implementasi Kebijakan Relaksasi Kredit Pada Masa Pandemi Covid-19 Di PT. Bank Rakyat Indonesia (Persero) Tbk", Jurnal Kompetitif Bisnis Edisi COVID-19, Volume 1 Number 1, 2020, p. 89.

${ }^{6}$ Departemen Pendidikan Nasional, Kamus Besar Bahasa Indonesia: Pusat Bahasa, Edisi Keempat, Gramedia Pustaka Utama, Jakarta, 2008, p. 1794. 
according to Article 1 paragraph 6 of Law Number 37 of 2004 concerning Bankruptcy and Postponement of Debt Payment Obligations (PKPU), debt is an obligation that is stated or can be stated in an amount of money either in Indonesian currency or foreign currency, either directly or that will arise in the future or contingent, arising from an agreement or Law and which must be fulfilled by the Debtor and if not fulfilled, entitles the Creditor to obtain fulfillment from the assets of the Debtor.

The broad definition of debt in Law number 37 of 2004 has an impact on defaults that can be resolved through the mechanism of bankruptcy law and suspension of debt payment obligations (PKPU) because the default in contract law can be considered as debt in the Law. This is also related to the ease of requirements for submitting an application for a declaration of bank bankruptcy does not confirm which debt conditions can be used as the basis for submitting an application for a declaration of bank bankruptcy ${ }^{7}$ In simple terms, bank bankruptcy general confiscation of the assets of the bankrupt Debtor. ${ }^{8}$ Under these conditions, it is possible for business actors to end their company or business in bankrBankruptcyly.

With the COVID-19 Pandemic which has paralyzed various sectors, especially the business sector, and also the ease of filing requirements for Bankruptcy and Suspension of Debt Payment Obligations (PKPU) as regulated in Law number 37 of 2004, one of the reasons for the increase in filings under conditions of COVID-19 Pandemic. According to Airlangga Hartarto, the Coordinating Minister for the Economy stated that there was an increase in the number of cases in filing for Bankruptcy and Suspension of Debt Payment Obligations (PKPU), to 430 cases in courts in Jakarta, Surabaya, and others. ${ }^{9}$ Thus, this writing will focus on the provisions related to BankrBankruptcythe Submission of Debt Payment Obligations and the urgency of Revision of Law Number 37 of 2004 concerning Bankruptcy and Filing of Debt Payment Obligations.

\section{METHOD}

This research is normative juridical research, namely legal research conducted by examining materials with literature or other secondary

\footnotetext{
7Jitia Damlah, "Akibat Hukum Putusan Kepailitan Dan Penundaan Kewajiban Pembayaran Utang Berdasarkan Undang-Undang Nomor 37 Tahun 2004", Lex Crimen, Volume 6 Number 2, 2017, p. 91.

${ }^{8}$ Rifqani Nur Fauziah Hanif, "Kepailitan dan Akibat Kepailitan Terhadap Kewenangan Debitur Pailit Dalam Bidang Hukum Kekayaan", DKJN Kemenkeu, October 16, 2020, accessed from https://www.djkn.kemenkeu.go.id/artikel/baca/13451/Kepailitan-dan-Akibat-Kepailitan-TerhadapKewenangan-Debitur-Pailit-Dalam-Bidang-Hukum-Kekayaan.html.

${ }^{9}$ Idris Rusadi Putra, "Pengajuan PKPU dan Kepailitan Meningkat Jadi 430 Kasus Selama Pandemi Covid-19", Merdeka, August 24, 2021, accessed from https://www.merdeka.com/uang/pengajuanpkpu-dan-kepailitan-meningkat-jadi-430-kasus-selama-pandemi-covid-19.html.
} 
data. ${ }^{10}$ This method examines the Law normatively by looking at the Law from an internal perspective whose object of research is to use legal norms that regulate the Postponement of Debt Payment Obligations. To collect these materials by studying the legal literature relating to the subject matter, other laws and regulations, legal articles, and various written sources.

\section{RESULT AND DISCUSSION}

\section{A. Provisions Regarding Filing of Obligations for Payment of Debt and Bankruptcy}

Bankruptcy and PKPU are related to debts between a person who lends money is called a creditor, and someone who lends money is called a debtor. In the event of such lending and borrowing, they make a letter of agreement with the intention of stating that the parties, namely the Debtor and Creditor, agree on the borrowing. That way, the parties are bound by the agreement because every agreement applies to the Law for the parties (Pacta Sunt Servanda). In accordance with article 1338 of the Civil Code, which reads those agreements made legally apply as Law for those who make them. This makes the parties have achievements that must be fulfilled in accordance with the agreement or agreement they made. ${ }^{11}$

The Debtor, as the party lent the debt, has an obligation, one of which is to repay the debt. Problems can arise if it turns out that the Debtor has difficulty in repaying his debt or is hampered in fulfilling his achievements. There are many ways to solve this problem, starting from litigation and nonlitigation. ${ }^{12}$

If through litigation, the Debtor may apply for the Suspension of the Obligation for Payment of debt to the Chairman of the Commercial Court. Based on Article 222 paragraph (2) of law number 37 of 2004 states that "Debtors who cannot or expect not to be able to continue paying their debts that are due and can be collected, can request a postponement of debt payment obligations, with the intention of submitting a reconciliation plan which includes an offer to pay part or all of the debt. to Creditors." It can be seen that PKPU is a delay in paying debts through a commercial judge's decision where creditors and debtors are given the opportunity to negotiate

\footnotetext{
10 Soerjono Soekanto dan Sri Mahmudji, Penelitian Hukum Normatif, Suatu Tinjauan Singkat, Raja Grafindo Persada, Jakarta, 2003, p. 13.

${ }^{11}$ Niru Anita Sinaga, "Implementasi Hak Dan Kewajiban Para Pihak Dalam Hukum Perjanjian", Jurnal Ilmiah Hukum Dirgantara, Volume 10 Number 1, 2019, p. 3.

${ }^{12}$ Stevi G. Tampemawa, "Prosedur Dan Tatacara Penundaan Kewajiban Pembayaran Utang (Pkpu) Menurut Undang-Undang No.37 Tahun 2004 Tentang Kepailitan Dan Penundaan Kewajiban Pembayaran Utang", Lex Privatum, Volume 7 Number 6, 2019, p. 5.
} 
related to these debts, and debt restructuring can also be carried out with all or part of the debt by also looking for ways of payment. The debt. ${ }^{13}$

Basically, this submission aims to reconcile the Debtor with the creditors and prevent the Debtor from being declared bankrupt. Bankruptcy is a general confiscation of all assets of the Debtor whose management and implementation is carried out by the Curator under the supervision of the Supervisory Judge. The assets will later be distributed to the creditors. Based on Article 2 paragraph (1) of Law Number 37 of 2004, it is stated that "a debtor who has two or more creditors and does not pay off at least one debt that has matured and can be collected, is declared bankrupt by a court decision either at his own request or at his request. At the request of one or more of its Creditors". ${ }^{14}$ From the statement, it is known that the conditions for the declaration of bank bankruptcy.

a. The Debtor has at least 2 (two) Creditors;

b. The Debtor does not pay in full at least 1 (one);

c. The Debtor's debt has matured and is collectible;

$\mathrm{d}$. There is a court decision, in this case the competent authority is the commercial court.

Before being declared bankrupt by the commercial court, the Debtor may apply for a PKPU first, the process for submitting a PKPU application is as follows:

1. The PKPU application can be submitted by debtors or creditors by fulfilling formal and substantial requirements, namely in accordance with Law Number 37 of 2004 and signed by the Debtor together with his legal counsel.

2. After the commercial court receives the application, the commercial court must grant the temporary PKPU application and determine a Supervisory Judge and appoint one or more administrators together with the Debtor to manage the Debtor's assets for a period of no later than 3 (three) days if the debtor registers, while by the Creditor no later than 20 days. ${ }^{15}$

3. The judge through the clerk must call the parties to hold a trial so that the judge can decide whether to determine or reject. Court judges no later than 45 days.

\footnotetext{
${ }^{13}$ Munir Fuadi, Hukum Pailit, Ctk. Pertama, PT. Citra Aditya Bakti, Bandung, 1999, p. 15.

${ }^{14 N i r u}$ Anita Sinaga dan Nunuk Sulisrudatin, "Hukum Kepailitan Dan Permasalahannya Di Indonesia", Jurnal Ilmiah Hukum Dirgantara, Volume 7 Number 1, 2016, p. 161-162.

${ }^{15}$ Kintan Ayunindya, "Solusi Sengketa Utang Piutang: PKPU”, bplawyers, January 02, 2020, accessed from https://bplawyers.co.id/2020/01/02/solusi-sengketa-utang-piutang-pkpu/.
} 
4. During the trial, if the concurrent creditors and/or creditors receiving material guarantees agree to a PKPU or a settlement, the court grants the postponement of the obligation to pay debts.

5. However, if the concurrent Creditors and/or Creditors receiving material guarantees do not agree to this Permanent PKPU or its extension or have exceeded the maximum period of 270 days or the number of days that have been determined, no agreement can be reached on the peace plan, then upon notification from the management, the Commercial Court must declare that the Debtor is bankrupt. 16

The bankruptcy filing process According to Law Number 37 of 2004 as follows: ${ }^{17}$

1. In article 6, paragraph 2, the application for a declaration of bankrBankruptcyresented to the Chairperson of the Court.

2. In article 6, paragraph 5, the court determines the day of the trial within a period of 3 (three) days after the date the application is registered.

3. In article 6, paragraph 6, the examination session is held within a period of no later than 20 (twenty) days after the date the application is registered.

4. In article 8, paragraph 1, the court is obliged to summon the Debtor if the application for bankrBankruptcyiled by the Creditor, the Prosecutor's Office, Bank Indonesia, the Capital Market Supervisory Agency, or the Minister of Finance. If submitted by the Debtor, the court may summon the Creditor and there is doubt that the bankruptcy requirements have been met.

5. In Article 8, paragraph 2, the summons is carried out by the bailiff by registered express letter no later than seven days before the first trial is held.

6. In article 8, paragraphs 5 and 6, the application for bankruptcy declaration must be granted if there are facts or circumstances that are simply proof that the requirements to be declared bankrupt have been fulfilled. No later than 60 (sixty) days after the date the petition for a declaration of bankrBankruptcyegistered, the Court's Decision must be pronounced.

\footnotetext{
${ }^{16} \mathrm{Ni}$ Nyoman Juliantini, I Made Arjaya, \& Ida Ayu Putu Widiati, "Procedures and Legal Consequences of Postponing the Obligation of Payment of Limited Liability Company Debt (Case Study Decision Number 03/PKPU/2010/PN.Niaga.Sby)", Journal of Legal Analogies, Volume 3 Number 1, 2021, p. 103-104.

17 Republik Indonesia, Undang-Undang Nomor 37 Tahun 2004 Tentang Kepailitan Dan Penundaan Kewajiban Pembayaran Utang, accessed from https://peraturan.bpk.go.id/Home/Details/40784.
} 
7. In article 8, paragraph 7 , the decision on the petition for a declaration of bank bankruptcy contain in full the legal considerations underlying the decision along with the opinion of the panel of judges and must be pronounced in a trial that is open to the public and can be implemented first, even though the decision has legal remedies.

Based on the bankruptcy filing process and PKPU From this it is clear that bank Bankruptcy is the last resort for debtors to pay their debts. Based on Article 229 paragraph (3) of Law Number 37 of 2004 that the PKPU application must be decided first if the bankruptcy declaration application and the PKPU application are being examined at the same time. ${ }^{18}$ The existence of priority in the PKPU application can anticipate debtors in a bank bankruptcy.

\section{B. Increased Filing of Bankruptcy and Suspension of Debt Payment Obligations (PKPU) as Urgency for Revision of Law Number 37 of 2004}

Economic development has a good impact on every developing country towards a developed country, the benchmark is in the Gross National Income (GNP) in each country. Indonesia itself is a country that is moving to change the economic status of a country from developing to developing. However, after the Covid-19 Pandemic caused all countries in Indonesia to experience an economic downturn, this was due to the many economic sectors that were affected by the arrival of the Covid-19 Pandemic, such as tourism, restaurant, travel, and many more sectors. This condition of economic sluggishness is due to the impact of social restrictions policies to reduce the spread of Covid-19. Indonesia itself had experienced its lowest point as a result of the impact of the Covid-19 Pandemic until the exchange rate of the Rupiah against the Dollar reached $16^{19}$, this makes many companies whose financial condition is sluggish and even lose because of the lack of income received during the Pandemic.

The increase in PKPU and Bankruptcy filings in commercial courts is one of the impacts of the Covid-19 Pandemic and is based on the loan debt submitted in order to maintain the continuity of the company, also supported by regulations regarding bankruptcy filings and PKPU which do not explicitly

\footnotetext{
18 Putu Eka Trisna Dewi, "Implementasi Penundaan Kewajiban Pembayaran Utang (Pkpu) Dalam Kepailitan Ditinjau Dari Undang-Undang Nomor 37 Tahun 2004 Tentang Kepailitan Dan Penundaan Kewajiban Pembayaran Utang", Jurnal Hukum Saraswati (JHS), Volume 1 Number 2, 2019, p. 282-283.

19 Rifaldi Virdaus, "Kondisi Perekonomian di Indonesia Selama Pandemi Covid-19", Kompasiana, April 14, 2020, accessed from https://www.kompasiana.com/rivaldifirdaus1407/5e9575f8d541df16776d47c2/dampakperekonomia n-di-indonesia-selama-pandemi-covid-19.
} 
regulate the amount of debt that can be filed for bankrBankruptcyhe principle of Indonesian bankruptcy law is regulated in general in Article 1131 of the Civil Code and specifications contained in Law Number 37 of 2004 concerning Bankruptcy and PKPU. ${ }^{20}$. These regulations are not only addressed to individuals, but companies can also be bankrupt. When a company is declared bankrupt, the impact will be bad because even before bankrBankruptcyre have been many reductions in employees in order to maintain the effectiveness of the company's expenses.

Bankruptcy based on Article 1 point 1 of Law Number 37 of 2004 concerning Bankruptcy and PKPU defines BankrBankruptcyeneral confiscation of all assets of the Bankrupt Debtor whose management and settlement is carried out by the Curator under the supervision of the Supervisory Judge as regulated in this Law. From the article, it is clear that when a company or individual is declared bankrupt, it means that all of their assets are used to pay off loans that cannot be paid to creditors. The distribution of the assets of the Debtor declared bankrupt is carried out by the Curator by taking into account the aspects of the type of Creditor in a bank bankruptcy. The Debtor is declared bankrupt if it fulfills the provisions of Article 2 paragraph (1) of the Bankruptcy Law and PKPU if it meets the following requirements:

First, the Debtor has 2 or more creditors and is unable to pay off at least one debt that is due and collectible. The Debtor can be declared bankrupt through a court decision, either at his own request or at the request of one or more creditors. The existence of two creditors is a requirement stated in the Bankruptcy Law and PKPU Number 37 of 2004. The provisions of Article 1132 of the Civil Code states that the assets of the Debtor must be divided fairly among creditors based on their types.

Second, the Debtor does not pay at least one debt to one of the creditors, which means the debtor defaults regardless of the nominal amount that can be submitted to the commercial court because in Law Number 37 of 2004 Article 2 paragraph 1 of the Bankruptcy Law and PKPU it does not clearly explain the nominal amount of the debt in question. One debt in the article in the sense when a debtor is negligent in paying his debts more than once. This situation is an absolute condition for the declaration of bank bankruptcy addition to several problems in bankruptcy enforcement, PKPU also has many problems. Based on the bankruptcy law and PKPU, especially in relation to creditors requesting a postponement of debt payment obligations. The Bankruptcy Law

${ }^{20}$ Syamsudin Syamsudin Sinaga, Hukum Kepailitan Indonesia, Tatanusa, Jakarta, 2012, p. 34. 
and PKPU open the right for Creditors to request a suspension of their debt payment obligations if the Debtor is deemed unable to repay his debt. However, it is the Debtor who makes the transaction plan with all the Creditors. This provision is unusual in the international insolvency system. Because PKPU is intended for the interest of the Debtor, it has the right to request debt restructuring in accordance with the ability of the Debtor. Moreover, PKPU is often misused to bankrupt debtors who can no longer pay their debts because after PKPU, there is no other solution other than bank bankruptcy.

Purpose of PKPU is as one of the settlements through the court, which is intended so that debts owned by debtors and which have matured can be postponed without any seizure of assets if at the same time there are several creditors who collect their debts simultaneously, and can be settled without having to confirm the creditors. In addition, to avoid the existence of creditors holding material security rights selling goods belonging to the Debtor in order to claim their rights by ignoring other creditors, as well as to avoid fraud committed by one of the creditors or debtors. ${ }^{21}$

In submitting a PKPU application in accordance with Article 222 paragraph (1) of the Bankruptcy Law and PKPU, it stipulates that the postponement of debt payment obligations shall be submitted by debtors who have more than one Creditor or by creditors. The PKPU application should only be submitted by the Debtor. The fact is that currently, PKPU is actually mostly submitted by creditors because the Bankruptcy Law and PKPU allow it. The provisions of Article 222 paragraph (1) of the Bankruptcy Law and this PKPU can have a negative impact, especially on debtors where creditors file a PKPU against the Debtor, but when the Debtor submits a reconciliation plan, ${ }^{22}$

Therefore, the methods of filing a PKPU lawsuit need to be studied further because this provision is detrimental to the Debtor and beneficial to Creditors who wish to bankrupt the Debtor. This needs to be considered more deeply to emphasize that the submission of a PKPU application can only be submitted by the Debtor either voluntarily or as a rebuttal to the bankruptcy application against the Debtor because basically, the one who knows well about the financial condition and ability to pay of the Debtor is the Debtor himself and not the Creditor. However, if the Creditor is still able to apply for a PKPU, then of course the PKPU decision must open the door of appeal for the Debtor.

\footnotetext{
${ }^{21}$ Sutan Remy Sjahdeini, Sejarah, Asas, dan Teori Hukum Kepailitan, Prenadamedia Group, Jakarta, 2016, p 61.

${ }^{22}$ Sherly Saputri, "Kedudukan Kreditor Separatis Dalam Penundaan Kewajiban Pembayaran Utang", Tesis, Upt Perpustakaan Universitas Andalas, 2015, p. 9.
} 
Problems that arise with Law Number 37 of 2004 concerning Bankruptcy and PKPU are several creditors who are considered to be unable to repay their debts again, or even the Debtor has bankrupted himself to avoid payments, which is certainly inconvenient to divide the assets of the company or individual Debtor to creditors who is not able to pay and prefer the mechanism for the distribution of assets of the company and individual debtors through a court mechanism.

The looseness of the rules contained is proven by the increase in filing for bankrBankruptcyPKPU in the Commercial Court. Chairman of Apindo, Hariyadi Sukamdani, said that PKPU and bankruptcy applications in five general commercial courts in 2020 reached 747 companies. Meanwhile, until August 2021, there were 551 companies, a drastic increase compared to 280 in 2019 and 193 cases in 2018. ${ }^{23}$ This condition not only affects workers who lose their jobs but also companies that easily delegate payment matters by filing PKPU and Bankruptcy to the commercial court. Do not let loose regulations and do not specify the amount of debt as an opportunity for companies and individuals who are looking for loopholes to avoid their payment obligations.

Indonesia itself has issued and revised regulations governing bankrBankruptcyely as many as 3 (three) laws and regulations which are products of national Law starting from the issuance of Government Regulation in Lieu of Law (PERPU) No. 1 of 1998 concerning Amendments to the Law on Bankruptcy which was later upgraded to Law no. 4 of 1998 and finally on November 18, 2004, it was further refined by Law Number 37 of 2004 concerning Bankruptcy and PKPU. ${ }^{24}$ The urgency in the revision of Law Number 37 of 2004 concerning Bankruptcy and PKPU covers several aspects. First, the Bankruptcy Law and the PKPU itself emerged based on the need for legal instruments aimed at solving debt problems in a fair, fast, open, and effective manner. Since its promulgation on November 8, 2004, until now there are still several articles, such as article 2 paragraph 1 , which do not provide legal certainty, especially in protecting the sustainability of debtors' business aspects. ${ }^{25}$

The conditions for bankrBankruptcyccordance with Article 2 paragraph (1) of the Bankruptcy Law and PKPU stipulate that a debtor who has two or more creditors and does not pay off at least one debt that has matured and is

\footnotetext{
${ }^{23}$ Anisa Ayu Artanti, "551 Perusahaan Ajukan PKPU dan Pailit saat Pandemi”, MSN, September 07, 2021, accessed from https://www.msn.com/id-id/berita/other/551-perusahaan-ajukan-pkpu-danpailit-saat-pandemi/ar-AAObbq5.

${ }^{24}$ Sri Rejeki Hartono, Hukum Kepailitan, UMM Press, Malang, 2008, p. 10.

${ }^{25}$ Freddy Josep, “Perlukah Revisi Undang-Undang Kepailitan? (Suatu Kajian Mengenai Imbas Kasus Manulife Dan Prudential", Jurnal Hukum dan Kepailitan, Volume 34 Number 1, 2017, p. 68.
} 
collectible, is declared bankrupt by a court decision, either at his own request or at his request. one or more creditors. Based on these provisions, it can be seen that the requirements for submitting a bankruptcy application are: (1) there must be debt, (2) one of the debts has had sufficient time and can be collected, and (3) the Debtor has at least two or more creditors. The conditions for bankrBankruptcytipulated in Article 2 paragraph (1) of the Bankruptcy Law and this PKPU are very simple, the Debtor can be declared bankrupt by the Commercial Court when the three conditions for bankrBankruptcymet. ${ }^{26}$ It should be related to the requirements to be declared bankrupt there is a minimum amount of Debtor that can no longer be paid. This needs to be done so that not all debtors have a relatively small amount of debt, if they meet all the requirements in Article 2 paragraph (1) of the Bankruptcy Law and PKPU, they can immediately be bankrupt.

Simple evidence that is in accordance with the purpose of the Bankruptcy Law and PKPU, namely the fair, fast, open, and effective settlement of debt and credit problems has not been well understood by judges in commercial courts. ${ }^{27}$ Article 8 paragraph (4) of the Bankruptcy Law and PKPU regarding simple evidence states that the judge must grant it if it proven that there is a simple situation. Problems that arise related to the development of civil relations are the difficulty of knowing the difference between easy or difficult debt, besides that there are also no regulations that can be used as simple parameters. This problem encourages judges to agree or not to grant the petition for bank Bankruptcy as there is a fact that the debt is due and the debt is due.

In practice, there is confusion about the implementation of the ladder of Creditor's claim priority. There is no legal certainty regarding the implementation of separatist rights when faced with tax collection rights and labor collection rights. On the one hand, the Bankruptcy Law and PKPU must also provide clarity regarding the rights of separate creditors, tax collection rights, and labor rights. ${ }^{28} \mathrm{Also}$ included in this case are the wages of workers, which based on the decision of the Constitutional Court Number 67/PUU$\mathrm{XI} / 2013$ decided Article 95 paragraph (4) of the Manpower Law is contrary to the 1945 Constitution and has no binding legal force as long as it is not interpreted as "payment of workers' wages". Indebtedness takes precedence

${ }^{26}$ Tata Wijayanata, "Kajian Tentang Pengaturan Syarat Kepailitan Menurut UU Nomor 37 Tahun 2004", Jurnal Mimbar Hukum, Volume 26 Number 1, 2014, p. 3.

${ }^{27}$ Ahmad Fauzi, "Pembuktian Sederhana dalam Kepailitan Koperasi yang Diajukan oleh Karyawan (Studi Kasus Kepailitan Pusat Koperasi Industri Susu Sekar Tanjung)", Skripsi Universitas Sumatera Utara, 2021, p. 6.

${ }^{28}$ Wulandari Rima Ramadhani,"Kreditor Separatis vs. Upah Buruh: Suatu Kajian Dalam Hukum Kepailitan." Media Iuris, Volume 4 Number 1, 2021, p. 120. 
over all types of Creditors, including claims for separatist Creditors, claims for state rights, auction offices, and public bodies established by the Government, while payments for other workers' rights take precedence over all claims, including claims for state rights, auction offices, and other agencies which are formed by the Government, except for claims from separatist Creditors". Based on the decision of the Constitutional Court, the wages of workers must be prioritized in the case of company bankruptcy. ${ }^{29}$

PKPU time is very short. The basic idea of PKPU is to give debtors an opportunity to reorganize or reorganize their business. The company's debt restructuring takes place over a long period of time. In fact, the time limit given by the bankruptcy law is only 45 days. Debtors are concerned that the 45-day deadline will create inequality of rights, which benefits creditors because of the difficulty of lobbying and debt restructuring used to offer peace proposals. ${ }^{30}$ The high vote count requirements and the cumulative voting requirements of the separatist creditors and congruent creditors, as regulated in Article 281 of the Bankruptcy Law and PKPU, are the main reasons why PKPU legal remedies are considered burdensome to the Debtor. In fact, this is also the main obstacle to peace proposals submitted by Debtors, which often fail. It often happens, even only about a year after approval of the component plan, the Debtor fails to pay his debt because he has to convince the Creditor about the plan implemented in the peace proposal to get a vote, but in the end, the Debtor goes bankrupt and ends up in bank bankruptcy. ${ }^{31}$

In addition, among the various problems that have not been regulated and as input in the Draft Civil Procedure Code and Bankruptcy Law and PKPU, a clear mechanism is needed between bankruptcy settlement and related PKPU with confiscation of bail in criminal cases. So far, the submission of applications for bankrBankruptcyPKPU is unclear in resolving cases because they are still waiting for the settlement of ongoing criminal cases. ${ }^{32} \mathrm{As}$ well as the position of the arbitration decision on bankruptcy decisions in commercial law courts, because when the Debtor takes alternative legal remedies, namely arbitration with other creditors, but the decision is

29 Doni Budiono, "Analisis Pengaturan Hukum Acara Kepailitan dan Penundaan Kewajiban Pembayaran Utang", ADHAPER: Jurnal Hukum Acara Perdata, Volume 4 Number 2, 2019, p. 121.

${ }^{30}$ Catur Irianto, "Penerapan Asas Kelangsungan Usaha Dalam Penyelesaian Perkara Kepailitan Dan Penundaan Kewajiban Pembayaraan Utang (PKPU)". Jurnal Hukum dan Peradilan, Volume 4 Number 3, 2015, p. 400.

${ }^{31}$ omi Adinda Putri Hasan, "Pengaruh Likuiditas Perusahaan dan Pembatalan Perjanjian Perdamaian dalam UU Nomor 37 Tahun 2004 Tentang Kepailitan dan Penundaan Kewajiban Pembayaran Utang terhadap Kepailitan Perusahaan" Skripsi, Universitas Sebelas Maret, 2019, p. 25.

32 Josua Fernando dan Susanti Adi Nugroho. "Kedudukan Sita Pidana Terhadap Sita Umum Kepailitan.", Jurnal Hukum Adigama, Volume 1 Number 1, 2018, p. 353. 
completed before the Debtor gets bankrupt status by another creditor, then what are the rights of the Creditor who has already resolved the debt problem through arbitration? Whether the applicant is included in the bankruptcy estate or is prioritized, even though when the Debtor has been declared bankrupt the status of ownership of the assets is transferred and managed by the Curator.

The moratorium proposal emerged after a National Coordination Meeting was held between the Coordinating Minister for Economic Affairs and the Indonesian Employers' Association (Apindo) which raised various pros and cons among various legal practitioners and the Indonesian Association of Curators and Administrators (AKPI). The revision of Law Number 37 of 2004 concerning Bankruptcy and PKPU is a wiser choice than the moratorium on Law Number 37 of 2004 concerning Bankruptcy and PKPU. The moratorium itself means the temporary suspension of regulations governing PKPU and Bankruptcy and replaced with the issuance of PERPPU, which will be issued by the president as a substitute for freezing of regulations governing PKPU and Bankruptcy. ${ }^{33}$

The revision of the regulation on Bankruptcy and PKPU is intended as the embodiment of the National Political Law, which is intended to create a National Legal System that can guarantee legal certainty, order and legal protection, which has the core of justice and truth, especially in settlement of debts and receivables. ${ }^{34}$ The moratorium decision will later lead to various problems where the rights of debtors who really cannot pay their debts and want to apply for PKPU are hampered and finally, the absence of restructuring of debt payment obligations to creditors further aggravates the condition of the company.

\section{CONCLUSION}

There is a need for consideration in making and stipulating bankruptcy arrangements, both in the Draft Civil Procedure Code and the Bankruptcy Law and Suspension of Debt Payment Obligations, especially on issues: the amount of debtor debt, simple evidence, creditors holding guarantees in bankrBankruptcyminal confiscation in bankrBankruptcyker wage rating, bankruptcy estate settlement, and position of the arbitration award. The lack of clarity in the rules in Article 2 paragraph 1 regarding the amount of debt and who can apply for bank bankruptcy necessity to motivate companies and

\footnotetext{
${ }^{33}$ Evi Dwi Hastri dan Rusfandi, "Conflict Interest yang Disebabkan Moral Hazard dalam Perumusan Kebijakan Moratorium Pailit dan PKPU", Jurnal Jendela Hukum, Volume 8 Number 2, 2021, p. 65.

${ }^{34}$ Sonny Triyono Saputra. "Perlindungan Hukum Bagi Kreditur Akibat Adanya Pailit yang Diajukan oleh Debitur Ditinjau dari Undang-Undang Kepailitan", Jurnal Rechtens, Volume 9 Number 1, 2020, p. 69.
} 
even to create a climate of struggle during the Covid-19 period so that they do not give up and are willing to innovate to advance their companies. For the commercial court to be more selective because the commercial court itself is prohibited from rejecting applications, referring to Article 16 paragraph (1) of Law no. 4 of 2004 concerning Judicial Power.

\section{DECLARATION OF CONFLICTING INTERESTS}

None

\section{FUNDING INFORMATION}

None

\section{ACKNOWLEDGEMENTS}

Thank you to Allah SWT, family and parties who have provided support in the implementation of this research and we also thank the Faculty of Law, Universitas Pembangunan Nasional Veterans Jakarta for the knowledge that has been given so far so that with this knowledge we can complete this research.

\section{REFERENCES}

Adhayanto, O. (2014). Perkembangan Sistem Hukum Nasional. Jurnal Ilmu Hukum, 4(2), 210-211.

Artanti, A. A. (2021) "551 Perusahaan Ajukan PKPU dan Pailit saat Pandemi", MSN, September 07, 2021, accessed from https://www.msn.com/id$\mathrm{id} /$ berita/other/551-perusahaan-ajukan-pkpu-dan-pailit-saatpandemi/ar-AAObbq5.

Ayunindya, K. (2020). "Solusi Sengketa Utang Piutang: PKPU”, bplawyers, January 02, 2020, diakses dari https://bplawyers.co.id/2020/01/02/solusisengketa-utang-piutang-pkpu/.

Budiono, D. (2019). Analisis Pengaturan Hukum Acara Kepailitan dan Penundaan Kewajiban Pembayaran Utang. ADHAPER: Jurnal Hukum Acara Perdata, 4(2), 121.

Damlah, J. (2017). Akibat Hukum Putusan Kepailitan Dan Penundaan Kewajiban Pembayaran Utang Berdasarkan Undang-Undang Nomor 37 Tahun 2004. Lex Crimen, 6(2), 91.

Departemen Pendidikan Nasional. (2008). Kamus Besar Bahasa Indonesia: Pusat Bahasa, Edisi Keempat. Jakarta: Gramedia Pustaka Utama.

Dewi, P. E. T. (2019). Implementasi Penundaan Kewajiban Pembayaran Utang (Pkpu) Dalam Kepailitan Ditinjau Dari Undang-Undang Nomor 37 
Tahun 2004 Tentang Kepailitan Dan Penundaan Kewajiban Pembayaran Utang. Jurnal Hukum Saraswati (JHS), 1(2), 282-283.

Fauzi, A. (2021). Pembuktian Sederhana dalam Kepailitan Koperasi yang Diajukan oleh Karyawan (Studi Kasus Kepailitan Pusat Koperasi Industri Susu Sekar Tanjung. Skripsi Universitas Sumatera Utara, 6.

Fernando, J., Nugroho S. A. (2018). Kedudukan Sita Pidana Terhadap Sita Umum Kepailitan Jurnal Hukum Adigama, 1(1), 353.

Fuadi, M. (1999). Hukum Pailit, Ctk. Pertama, Bandung: PT. Citra Aditya Bakti.

Hanif, R. N. F. (2020). "Kepailitan dan Akibat Kepailitan Terhadap Kewenangan Debitor Pailit Dalam Bidang Hukum Kekayaan”, DKJN Kemenkeu, October 16, 2020, accessed from https://www.djkn.kemenkeu.go.id/artikel/baca/13451/Kepailitan-danAkibat-Kepailitan-Terhadap-Kewenangan-Debitur-Pailit-DalamBidang-Hukum-Kekayaan.html.

Hartono, S. R. (2008) Hukum Kepailitan, Malang: UMM Press.

Hasan, N. A. P. (2019) Pengaruh Likuiditas Perusahaan dan PembatalanPerjanjian Perdamaian dalam UU Nomor 37 Tahun 2004 Tentang Kepailitan dan Penundaan Kewajiban Pembayaran Utang terhadap Kepailitan Perusahaan. Skripsi Universitas Sebelas Maret, 25.

Hastri, E. D., Rusfandi. (2021). Conflict Interest yang Disebabkan Moral Hazard dalam Perumusan Kebijakan Moratorium Pailit dan PKPU. Jurnal Jendela Hukum, 8(2), 65.

Irianto, C. (2015). Penerapan Asas Kelangsungan Usaha Dalam Penyelesaian Perkara Kepailitan Dan Penundaan Kewajiban Pembayaraan Utang (PKPU). Jurnal Hukum dan Peradilan, 4(3), 400.

Josep, F. (2017). Perlukah Revisi Undang-Undang Kepailitan? (Suatu Kajian Mengenai Imbas Kasus Manulife Dan Prudential. Jurnal Hukum dan Kepailitan, 34(1), 68.

Juliantini, N. N., Arjaya, I. M., \& Widiati, I. A. P. (2021). Prosedur Dan Akibat Hukum Penundaan Kewajiban Pembayaran Utang Perseroan Terbatas (Studi Kasus Putusan Nomor 03/PKPU/2010/PN.Niaga.Sby). Jurnal Analogi Hukum, 3(1), 103-104.

Misno B. P. A., Junediyono, et al. (2020). Covid-19: Wabah, Fitnah dan Hikmah, Bogor: Pustaka Amma Alamia.

Ningsih D. L. (2021) “Kondisi Pertumbuhan Ekonomi saat Pandemi Covid-19 di Indonesia", Yahoo berita, June 16, 2021, accessed from https://id.berita.yahoo.com/kondisi-pertumbuhan-ekonomi-saatpandemi-080201706.html.

Putra, I. R. (2021). “Pengajuan PKPU dan Kepailitan Meningkat Jadi 430 Kasus Selama Pandemi Covid-19", Merdeka, August 24, 2021, accessed from 
https://www.merdeka.com/uang/pengajuan-pkpu-dan-kepailitanmeningkat-jadi-430-kasus-selama-pandemi-covid-19.html

Ramadhani, W. R. (2021). Kreditor Separatis vs. Upah Buruh: Suatu Kajian Dalam Hukum Kepailitan. Media Iuris, 4(1), 120.

Reftiana, A., et al. (2020). Analisis Implementasi Kebijakan Relaksasi Kredit Pada Masa Pandemi Covid-19 Di PT. Bank Rakyat Indonesia (Persero) Tbk. Jurnal Kompetitif Bisnis Edisi COVID-19, 1(1), 89.

Republik Indonesia. (2004). Undang-Undang Nomor 37 Tahun 2004 Tentang Kepailitan Dan Penundaan Kewajiban Pembayaran Utang. Lembaran Negara Republik Indonesia Tahun 2004 Nomor 131, Tambahan Lembaran Negara Republik Indonesia Nomor 4443.

Saputra, S.T. (2020). Perlindungan Hukum Bagi Kreditur Akibat Adanya Pailit yang Diajukan oleh Debitor Ditinjau dari Undang-Undang Kepailitan." Jurnal Rechtens, 9(1), 69.

Saputri, S. (2015). Kedudukan Kreditor Separatis Dalam Penundaan Kewajiban Pembayaran Utang. Tesis, Upt Perpustakaan.

Sinaga, N. A. \& Sulisrudatin, N. (2016). Hukum Kepailitan Dan Permasalahannya Di Indonesia. Jurnal Ilmiah Hukum Dirgantara, 7(1), 161-162.

Sinaga, N. A. (2019). Implementasi Hak Dan Kewajiban Para Pihak Dalam Hukum Perjanjian. Jurnal Ilmiah Hukum Dirgantara, 10(1), 3.

Sinaga, S. (2012). Hukum Kepailitan Indonesia, Jakarta: Tatanusa.

Sjahdeini, S. R. (2016). Sejarah, Asas, dan Teori Hukum Kepailitan, Jakarta: Prenadamedia Group.

Soekanto, S. \& Mahmudji, S. (2003) Penelitian Hukum Normatif, Suatu Tinjauan Singkat, Jakarta: Raja Grafindo Persada.

Tampemawa, S. G. (2019). Prosedur Dan Tatacara Penundaan Kewajiban Pembayaran Utang (Pkpu) Menurut Undang-Undang No.37 Tahun 2004 Tentang Kepailitan Dan Penundaan Kewajiban Pembayaran Utang. Lex Privatum, 7(6), 5.

Virdaus, R. (2020). "Kondisi Perekonomian di Indonesia Selama Pandemi Covid-19", Kompasiana, April 14, 2020, accessed from https://www.kompasiana.com/rivaldifirdaus1407/5e9575f8d541df16776 d47c2/dampakperekonomian-di-indonesia-selama-pandemi-covid-19.

Wijayanata, T. (2014). Kajian Tentang Pengaturan Syarat Kepailitan Menurut UU Nomor 37 Tahun 2004. Jurnal Mimbar Hukum, 26(1), 3.

Yamali, F. R., \& Putri R. N. (2020). Dampak Covid-19 Terhadap Ekonomi Indonesia. Journal of Economics and Business, 4(2), 386. 


\section{ABOUT AUTHOR(S)}

Centia Sabrina Nuriskia, born in Batam, July 24, 2001. She is currently pursuing a Bachelor of Law with a concentration in Business Law at the Universitas Pembangunan Nasional Veterans Jakarta. Have an interest in Employment Law, legal drafting, and Business Law. Active in the organization of the Student Senate, Faculty of Law, Universitas Pembangunan Nasional Veterans Jakarta and several other organizations and committees. In addition, he is also actively participating in various seminars and workshops.

Ahmad Yoga Novaliansyah, born in Jakarta, November 08, 1999. He is currently pursuing a Bachelor of Law with a concentration in Business Law at Universitas Pembangunan Nasional Veterans Jakarta. Active in the Student Executive Board of the Jakarta Veterans National Development University and several other organizations and committees. In addition, he also actively participates in various seminar activities to support knowledge in the field of business law, especially company law, employment law, and the formation of legislation. 